\title{
Modification of natural zeolite by salt to treat ammonia pollution in groundwater
}

\author{
Biến tính zeolite tụ nhiên bằng muối ăn để xư lí amoni trong nước ngầm \\ Research article
}

Nguyen Xuan Huan*, Nguyen Thi Tham, Luu Quang Minh

Faculty of Environmental Sciences, VNU University of Science, Vietnam National University, Ha Noi

\begin{abstract}
Treating ammonium pollution in ground water by natural zeolite after being modificated to the Naform (Z-Na) is the new way of research that scientists interested in. The experiment results showed that, at $\mathrm{pH} 6$, the efficient of treating ammonium in ground water is the highest. The efficient of treating increase rapidly in the first 5 minutes and remain stable after that. Higher concentration of the Z-Na will increase the treating coefficient of the process. With a water sample that has $\mathrm{C}_{\mathrm{N}}$ $\mathrm{NH} 4_{+}=27 \mathrm{mg} / \mathrm{L}$ at first, using $\mathrm{C}_{\mathrm{Z}-\mathrm{Na}}=13 \mathrm{~g} / \mathrm{L}$ and after 5 minutes, the concentration of ammonium in water was declined to $1 \mathrm{mg} / \mathrm{L}$, passed the Vietnamese standard for ground water (QCVN 09:2015MT/BTNMT). The treating coefficient is $96.30 \%$, the adsorption capacity is $2.07 \mathrm{mg} \mathrm{N}-\mathrm{NH}_{4}{ }^{+} / 1 \mathrm{~g} \mathrm{Z}$ $\mathrm{Na}$. The loaded Z-Na was regenerated using $2 \mathrm{~g} / \mathrm{L} \mathrm{NaOH}$ solution, the ammonium recovery ratio exceeded $92 \%$. This means the reuse of Z-Na for ammonium adsorption is very high. The results of the experiment with groundwater samples in Phu Xuyen district, Ha Noi have a concentration of 53 $\mathrm{mg} / \mathrm{L}$. In conclusion, Z-Na material is perfectly fit for purpose of treating ammonium in ground water because of it low price, safety, easily to imitate and high efficiency.
\end{abstract}

Xư li ô nhiễm amoni trong nước ngầm bằng vật liệu zeolite tư nhiên được biến tính bằng muối ăn (Z-Na) là một huớng nghiên cứu mói, đuoợc các nhà khoa học rất quan tâm. Kết quả thí nghiệm cho thấy, tại pH 6 thì hiệu quả xử lí amoni trong nước là tốt nhất. Hiệu quả xủ lí amoni trong nước tăng rất nhanh trong 5 phút đầu tiên xủ lý. Càng tăng nồng độ Z-Na thì hiệu quả xủ lí amoni càng cao. Với dung dịch nuớc ban đầu có nồng độ amoni tính theo nito $\left(\mathrm{N}_{-} \mathrm{NH}_{4}^{+}\right)$nhỏ hơn $27 \mathrm{mg} / \mathrm{L}$ và nồng độ vật liệu Z-Na sủ dụng là $13 \mathrm{~g} / \mathrm{L}$ thì nước sau xủ lí có nồng độ nhỏ hơn $1 \mathrm{mg} \mathrm{N}-\mathrm{NH}_{4}^{+} / \mathrm{L}$, đạt QCVN 09-MT:2015/BTNMT, hiệu suất xủ lí đạt 96,30\%, dung luợng hấp phu cục đại đạt 2,07 mg $\mathrm{N}$ $\mathrm{NH}_{4}^{+} / \mathrm{lg} \mathrm{Z}-\mathrm{Na}$. Vật liệu Z-Na sau khi xủ lý đuợc nghiên cứu giải hấp bằng dung dịch $\mathrm{NaOH}$ vói nồng độ $2 \mathrm{~g} / \mathrm{L}$ cho thấy hiệu quả giải hấp đạt $92 \%$ luợng amoni được hấp phu. Điều này chứng tỏ khả năng tái sủ dụng của vật liệu Z-Na cho hấp phu amoni là khá cao. Kết quả nghiên cứu đã được thử nghiệm xử lý với mẫu nước ngầm tại huyện Phú Xuyên, Hà Nội có nồng độ $N-N_{4}{ }^{+}$là $53 \mathrm{mg} / \mathrm{L}$. Vì vậy, vật liệu Z-Na hoàn toàn có thể úng dụng vào thưc tiễn để xủ lý amoni trong nuóc ngầm rất an toàn, dễ thưc hiện và hiệu quả cao.

Keywords: natural zeolite, ammonia, groundwater

\section{Introduction}

According to many studies, the underground water sources in many localities in the country are seriously polluted with ammonium $\left(\mathrm{NH}_{4}{ }^{+}\right)$. Ammonia content in accordance with Vietnamese standards (QCVN 09-MT: 2015/BTNMT and QCVN 02: 2009/BYT) is $1 \mathrm{mg} / \mathrm{L}$ and $3 \mathrm{mg} / \mathrm{l}$, but many places in the Red river delta and the Cuu Long river delta, groundwater contaminated with ammonium is several times higher than the permissible level $[1,5,6]$.
When ammonium-contaminated groundwater is exposed to air, many species convert ammonium to nitrite and nitrate. Nitrit in the body competes with red blood cells for oxygen and causes respiratory disease (especially for pregnant women and children), on the other hand can also combine with organic substances to create substances that may cause cancer [4].

Because of the urgency of this matter that many studies have been conducted to find the best remedies possible to the best extent possible. In it, studying an $\mathrm{NH}_{4}{ }^{+}$treatment method suitable for household level water treatment is very 
important $[2,3,7,8]$. To do that, we need to find a material that can be denatured in a simple, easy to apply for family size. So the study chose the material Nitto Zeolite, and modified the material with salt to treat ammonia in groundwater.

In this study, sea salt was used to modify natural zeolite into a material that is capable of treating ammonium well in water. The study also found the significance of time, $\mathrm{pH}$, initial concentration on the efficiency of ammonia treatment by Z-Na.

\section{Materials and methods}

\subsection{Materials}

Ammonium contaminated water source: in the lab is modulation of ammonium solutions with different concentrations from $\mathrm{N}-\mathrm{NH}_{4}{ }^{+} 1000 \mathrm{mg} / \mathrm{L}$ solution, actual is water sample taken from a borehole of people in Phu Tuc commune, Phu Xuyen, Hanoi with $\mathrm{C}_{\mathrm{N}-\mathrm{NH} 4+} 53 \mathrm{mg} / \mathrm{l}$. Nitto Zeolite: natural Nitto Zeolite $\left(\left(\mathrm{Ca}, \mathrm{K}_{2}, \mathrm{Na}_{2}\right) \quad(\mathrm{Al}\right.$ $\left.\left.\mathrm{SiO}_{5} \mathrm{O}_{12}\right)_{2} .7 \mathrm{H}_{2} \mathrm{O}\right)$, natural Nitto Zeolite activated by sea salt (Z-Na).

\subsection{Methods}

\subsubsection{Modification of natural nitto zeolite $(Z)$ zeolite to sodium form (Z-Na)}

- Zeolite modification:

+ Add $120 \mathrm{~g}$ of Nitto Zeolite into $1 \mathrm{~L}$ of sea salt solution at $6 \mathrm{~g} / \mathrm{L}$ and shake well for 4 hours. Let dry we have Z-Na.

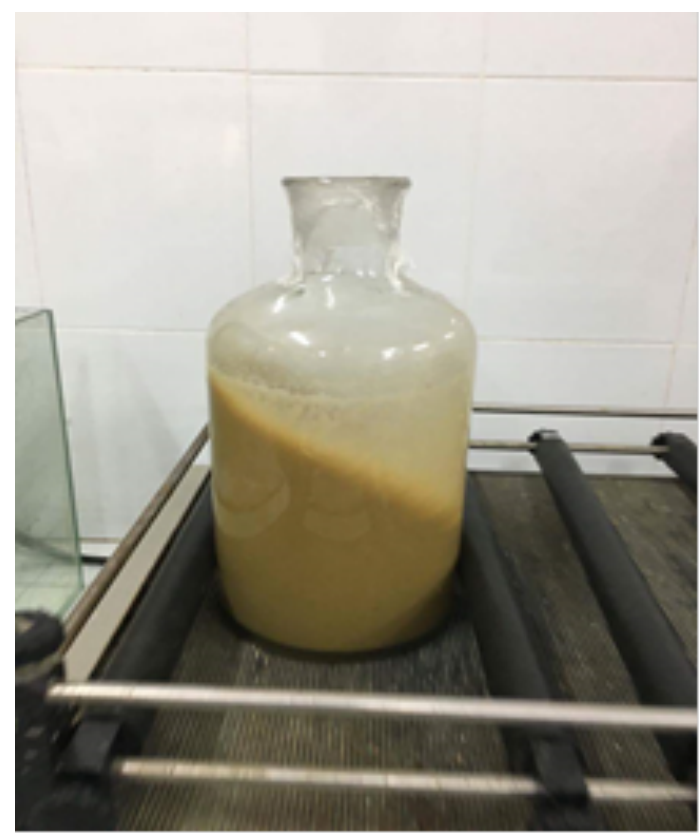

Figure 1. Activating Zeolite using sea salt

-Treatment mechanism:

Na-Zeolite $+\mathrm{NH}_{4}^{+} \rightarrow$ Zeolite- $\mathrm{NH}_{4}{ }^{+}+\mathrm{Na}^{+}$

$\mathrm{Na}$ in the cavities of the zeolite exchanged with the $\mathrm{NH}_{4}^{+}$ ion from the aqueous solution and resulted in $\mathrm{NH}_{4}{ }^{+}$entering the zeolite and sodium $\mathrm{Na}^{+}$go outside.
In a water source containing concurrent cations such as $\mathrm{Na}^{+}, \mathrm{Ca}^{2+}, \mathrm{Mg}^{2+}, \ldots$ competitive ion exchange occurs, which is more selective than ammonium ion, especially valence ions. Ammonia can only be exchanged when it is positive, $\mathrm{NH}_{4}{ }^{+}$in the neutral $\mathrm{NH}_{3}$ form is not exchangeable.

\subsubsection{Research content}

a. Comparison of processing efficiency between original Zeolite and Z-Na

Treatment of ammonium water samples with $\mathrm{C}_{\mathrm{N}-\mathrm{NH} 4+}=$ $40 \mathrm{mg} / \mathrm{L}$, Zeolite $13 \mathrm{~g} / \mathrm{L}, \mathrm{pH}=6, \mathrm{t}=5$ minutes with Nitto Zeolite and Z-Na.

b. Research the effect of initial ammonia to the processing efficiency

Use Z-Na with a concentration of $13 \mathrm{~g} / \mathrm{L}$ of aqueous solution to treat $\mathrm{N}_{-} \mathrm{NH}_{4}{ }^{+}$with concentration of $40 \mathrm{mg} / \mathrm{L}$ at $\mathrm{pH}$ $4,6,7,8,10$ with $0.01 \mathrm{M} \mathrm{HCl}$ standard solutions and $\mathrm{NaOH}$ $0.01 \mathrm{M}$ to adjust. Shake the sample for $1,2,3,5,10,15,20$, 30 minutes at room temperature then filter through filter paper. Determine the remaining $\mathrm{N}_{-} \mathrm{NH}_{4}{ }^{+}$concentration in the filtrate by spectrophotometry with nestle reagents.

\section{c. Processing efficiency affection result with different $\mathrm{Z}-\mathrm{Na}$ concentration}

Treatment of ammonium solution with concentration of $\mathrm{N}$ $\mathrm{NH}_{4}{ }^{+} 40 \mathrm{mg} / \mathrm{L}(\mathrm{pH}=6)$ with Z-Na concentration of 9; 11; $13 ; 15 ; 17$ and $20 \mathrm{mg} / \mathrm{L}$. Shake the sample for 5 minutes at room temperature, filter through filter paper. Determine the remaining $\mathrm{N}_{-} \mathrm{NH}_{4}{ }^{+}$concentration in the filtrate.

\section{d. Research the effect of initial ammonia to the processing efficiency}

Treatment of ammonium solution with $\mathrm{N}-\mathrm{NH}_{4}^{+}$concentration of $15 ; 20 ; 25 ; 30 ; 35$ and $40 \mathrm{mg} / \mathrm{L}(\mathrm{pH}=6)$ with $\mathrm{Z}-\mathrm{Na}$ $13 \mathrm{~g} / \mathrm{L}$, shake for 5 minutes at room temperature. Then filter through filter paper, determine the remaining $\mathrm{N}_{-} \mathrm{NH}_{4}{ }^{+}$.

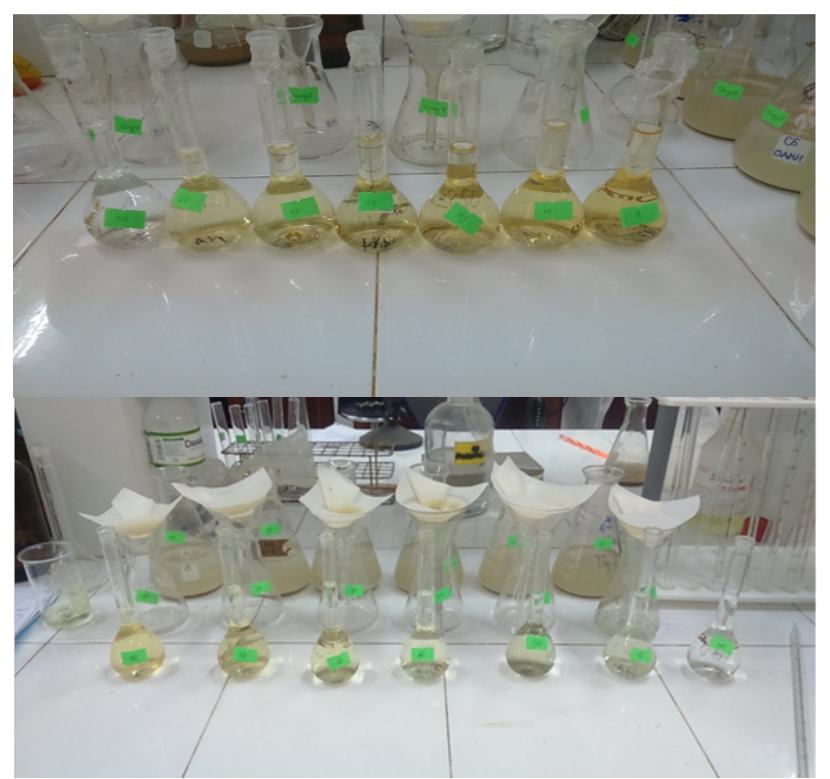

Figure 2. Examine the effect of $\mathrm{pH}$, time and concentration to the processing efficiency 


\section{e. Research the desorption ability of used Zeolite}

Use ammonium solution with $\mathrm{N}-\mathrm{NH}_{4}{ }^{+}$concentration of 80 $\mathrm{mg} / \mathrm{L}$ for $\mathrm{Z}-\mathrm{Na} 26 \mathrm{~g} / \mathrm{L}$ at $\mathrm{pH}=6$. Shake for 30 minutes then filter the residue.

Add $500 \mathrm{ml}$ of $\mathrm{NaOH}$ solution with concentration of $2 \mathrm{~g} / \mathrm{L}$, then shake for 30 minutes. From which, determine the concentration of $\mathrm{N}^{-\mathrm{NH}_{4}}{ }^{+}$in the solution. determine the discharge efficiency of the amount of ammonia adsorbed.

f. Research of ammonia treatment in Phu Tuc commune, Phu Xuyen, Hanoi

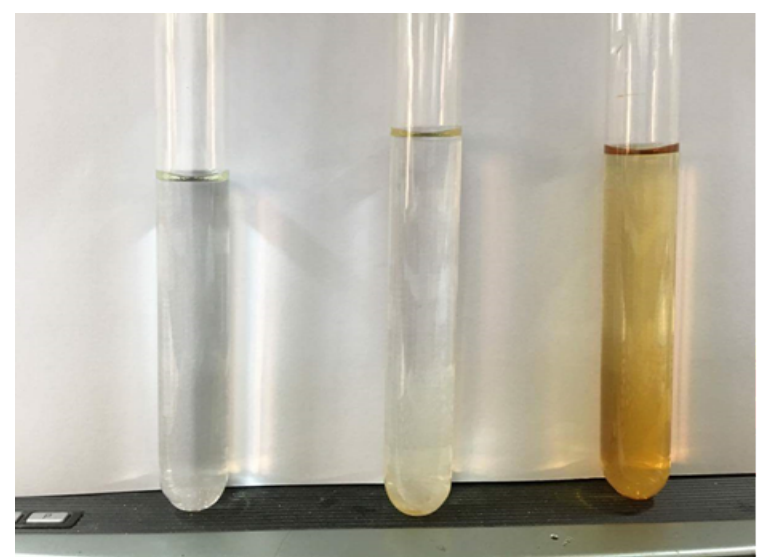

Figure 3. Treating ammonia in groundwater samples in Phu Tuc communce, Phu Xuyen, Ha Noi

(From left to right: Uncontaminated water; Ammonium contaminated water after treatment; Ammonium contaminated water before treatment).
Use Z-Na to treat the real sample (third test-tube) that has ammonia concentration of $17.5 \mathrm{~g} / \mathrm{L}$ and $25 \mathrm{~g} / \mathrm{L}$.

Treatment of ammonium water samples (Figure 3 ) with $\mathrm{C}_{Z}$ $\mathrm{Na}^{2}=25 \mathrm{~g} / \mathrm{L}$ (first test-tube) and $17.5 \mathrm{~g} / \mathrm{L}$ (second test-tube), $\mathrm{pH}=6, \mathrm{t}=5$ minutes.

\section{Results and discussion}

Currently, in Vietnam and on the world, water contaminated with ammonium is usually treated with methods such as chlorination to the mutation point, ion exchange method and biological method. These processes require high technology and large processing costs. So the study of modified zeolites has opened up a new way of dealing with household-scale ammonium contamination when similar studies in Vietnam and the world are relatively modest.

\subsection{Research results on Nitto Zeolite}

+ Structure: $\left(\mathrm{Ca}, \mathrm{K}_{2}, \mathrm{Na}_{2}\right)\left(\mathrm{AlSiO}_{5} \mathrm{O}_{12}\right)_{2} \cdot 7 \mathrm{H}_{2} \mathrm{O}$

+ Chemical composition of Nitto Zeolite (analysed with

$\mathrm{X}$-ray diffracted spectrum from VNU analytical center).

The results of table 1 show that the $\mathrm{SiO}_{2}$ content of zeolite is $65.15 ; \mathrm{Al}_{2} \mathrm{O}_{3}$ is 10.07 and $\mathrm{Fe}_{2} \mathrm{O}_{3}$ is $2.37 \%$. These are important elements that help zeolite process well $\mathrm{NH}_{4}{ }^{+}$in water.

Table 1. Chemical composition of Nitto Zeolite

\begin{tabular}{lrrrrrrr} 
Chemical Composition & $\mathbf{S i O}_{\mathbf{2}}$ & $\mathbf{A l}_{\mathbf{2}} \mathbf{O}_{\mathbf{3}}$ & $\mathbf{F e}_{\mathbf{2}} \mathbf{O}_{\mathbf{3}}$ & $\mathbf{C a O}$ & $\mathbf{K}_{\mathbf{2}} \mathbf{O}$ & $\mathbf{N a} \mathbf{O}_{2} \mathbf{M}$ & $\mathbf{M g O}$ \\
\hline Concentration (\%) & 65.15 & 10.07 & 2.37 & 2.41 & 2.07 & 1.35 & 0.22
\end{tabular}

- X-ray result of Nitto Zeolite material

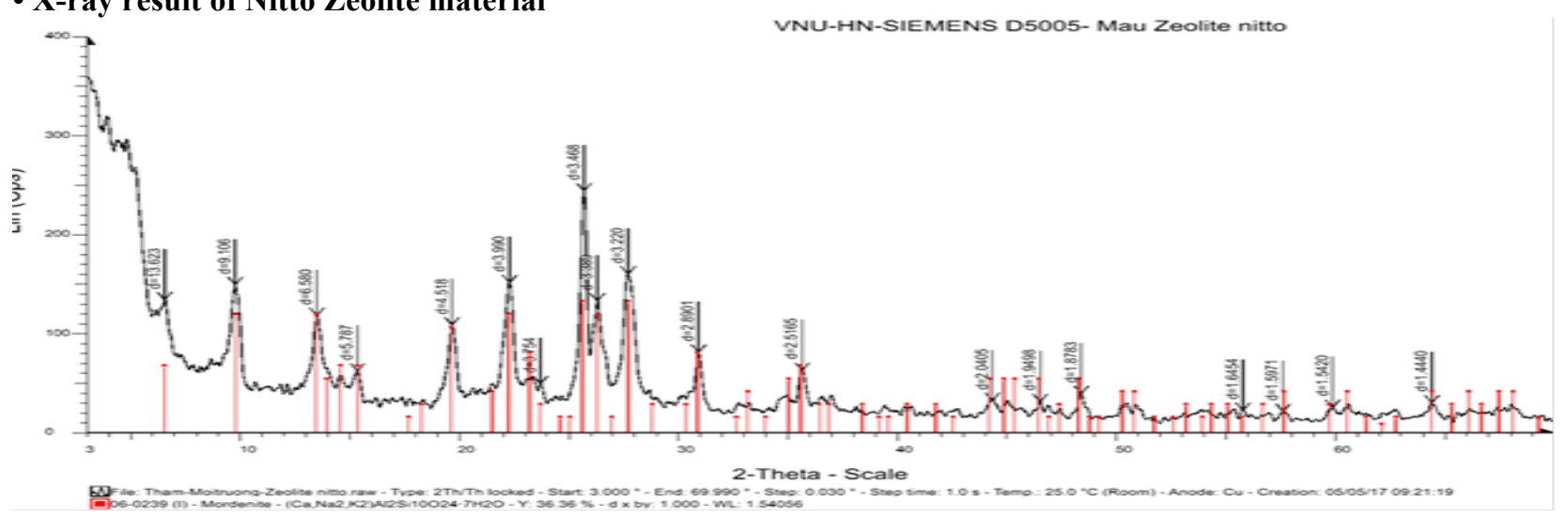

Figure 4. Diffracted spectrum X-ray of Nitto Zeolite

The XRD patterns confirmed Nitto Zeolite as the only phases present for the cocrystallized materials (Fig. 4). In the case of cocrystallized Nitto Zeolite the X-ray pattern showed the 8. 36, 14.56, 25.67, 27.03, 28.47, and 29.78 •, $2 \theta$ line characteristic of Nitto Zeolite. Nitto Zeolite showed peaks characteristic of completely dehydrated.

\subsection{Comparison of treating ammonia result between Zeolite and Z-Na}

Treatment of ammonium water samples with $\mathrm{CN}-\mathrm{NH}_{4}{ }^{+}=$ $40 \mathrm{mg} / \mathrm{L}$, results after treatment:

+ Nitto Zeolite: $\mathrm{CN}-\mathrm{NH}_{4}{ }^{+}$after treatment $=4.97 \mathrm{mg} / \mathrm{L}$, processing efficiency $=87 \%$

$+\mathrm{Z}-\mathrm{Na}: \mathrm{CN}^{-\mathrm{NH}_{4}}{ }^{+}$after treatment $=2.22 \mathrm{mg} / \mathrm{L}$, processing efficiency $=94.46 \%$. 
The results above show that the treatment efficiency of Z$\mathrm{Na}$ is higher than nitto zeolite.

\subsection{Processing efficiency affection result of ammonia with different $\mathrm{pH}$ and time}

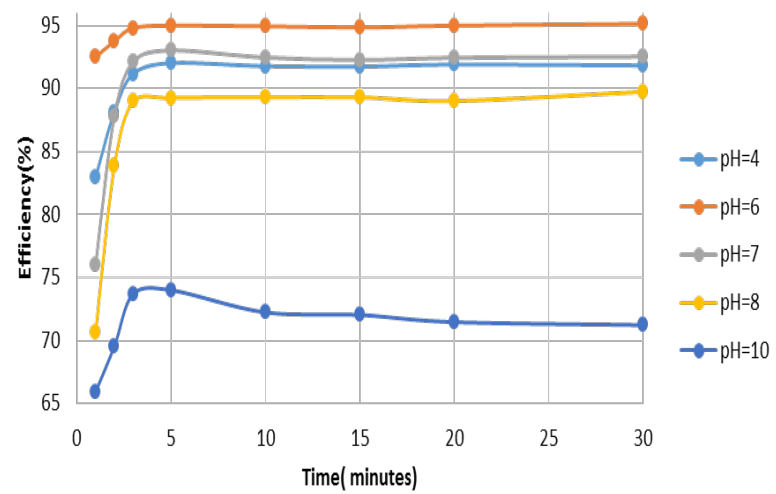

Figure 5. Processing efficiency result of ammonia with different $\mathrm{pH}$ and time

The results of the study in Figure 5 show the effect of ammonium treatment with $\mathrm{Z}-\mathrm{Na}$ as follows:

+ The efficiency of ammonia treatment in water with Z-Na increased rapidly in the first 5 minutes and almost did not increase much later. In the first 5 minutes, ammonia removal efficiency was over $96 \%$ during the process, a litte bit lower than $99 \%$ in comparison with $\mathrm{NaCl}$-modified
Yemeni zeolite (Alshameri et al. 2014) but their processing time is up to 120 minutes.

+ The best performance at $\mathrm{pH}=6$. At other $\mathrm{pHs}$, processing efficiency is still high, for example at $\mathrm{pH}=4$, processing efficiency is $92 \%$, or at $\mathrm{pH}=7$, the processing efficiency is $93 \%$. However, at $\mathrm{pH} 6$, the highest ammonium treatment efficiency was up to $95 \%$.

\subsection{Processing efficiency affection result with different $\mathrm{Z}$-Na concentration}

According to the results shown in Figure 6, the ammonium treatment efficiency increased as the concentration of $\mathrm{Z}-\mathrm{Na}$ increased.

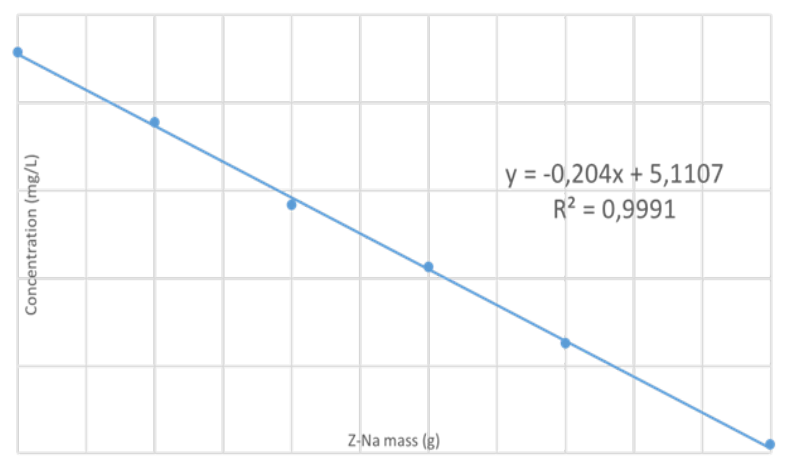

Figure 6. Processing efficiency with different concentration of $\mathrm{Z}-\mathrm{Na}$

\subsection{Processing efficiency affection result with different initial ammonia concentration}

Table 2. Concentration of amonia after treating and calculated data for Langmuir isotherm equation

\begin{tabular}{lrrrrr}
$\begin{array}{l}\text { Initial } \\
\text { concentration } \\
(\mathbf{m g} / \mathbf{l})\end{array}$ & $\begin{array}{r}\text { Ammonia } \\
\text { tration after treat- } \\
\text { ment, Ce (mg/l) }\end{array}$ & $\begin{array}{r}\text { Amount of ad- } \\
\text { sorbed substance } \\
(\mathbf{m g} / \mathbf{g})\end{array}$ & $\begin{array}{r}\text { Ce/Qe } \\
(\mathbf{g} / \mathbf{l})\end{array}$ & $\begin{array}{r}\text { QCVN } \\
\text { 09-MT:2015 } \\
\text { BTNMT }\end{array}$ & $\begin{array}{r}\text { QCVN } \\
\mathbf{0 2 : 2 0 0 9}\end{array}$ \\
\hline 40 & 2.21676 & 37.78324 & 0.05867 & 1 & 3 \\
35 & 1.7199 & 33.2801 & 0.05168 & 1 & 3 \\
30 & 1.20393 & 28.79607 & 0.041809 & 1 & 3 \\
27 & 0.99372 & 26.00628 & 0.038211 & 1 & 3 \\
25 & 0.86572 & 24.13428 & 0.035871 & 1 & 3 \\
20 & 0.53169 & 19.46831 & 0.027311 & & 3 \\
15 & 0.31024 & 14.68976 & 0.021119 & & 1
\end{tabular}

To determine the ammonium adsorption of $\mathrm{Z}-\mathrm{Na}$ material, study the effect of initial ammonium concentration on the ammonium removal efficiency in water by Z-Na. Results are shown in Table 2.

From the data in Table 2, it is possible to determine the Langmuir isotherm adsorption equation as follows:

$$
Q e=Q_{\max } \frac{b \cdot C_{e}}{1+b \cdot C_{e}}(1)
$$

In which: $\mathrm{Q}_{\mathrm{e}}$ is the adsorption capacity at the time of equilibrium $(\mathrm{mg} / \mathrm{g}), \mathrm{Q}_{\max }$ is the maximum absorption capacity $(\mathrm{mg} / \mathrm{g}), \mathrm{C}_{\mathrm{e}}$ is the concentration at equilibrium $(\mathrm{mg} / \mathrm{l}), \mathrm{b}$ is the constant that characterizes the interaction of the absorbent and the adsorbent.
The equation 1 can be transformed into the following form:

$$
\frac{C e}{Q e}=\frac{1}{Q \max } \cdot C e+\frac{1}{b \cdot Q \max }(2)
$$

The equation 2 is the linear equation representing the linear dependence of Ce/Qe on Ce. Replacing the empirical data from Table 2 into equation 2 we can establish the arsenic isothermal adsorption equation shown in Figure 7. 


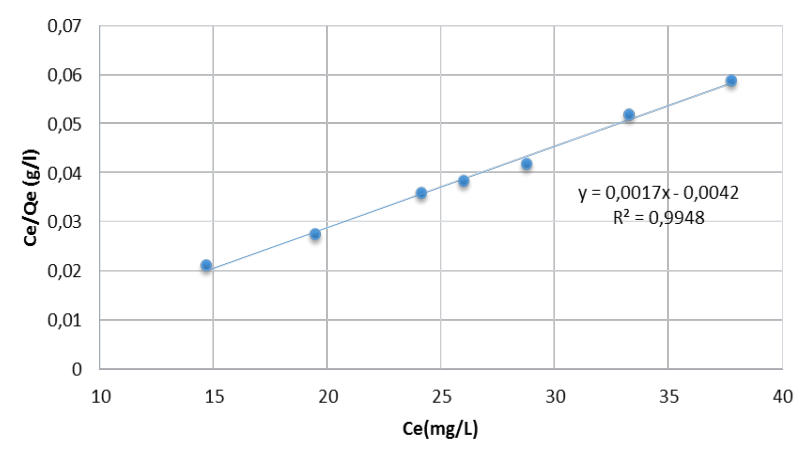

Figure 7. Langmuir isotherm line

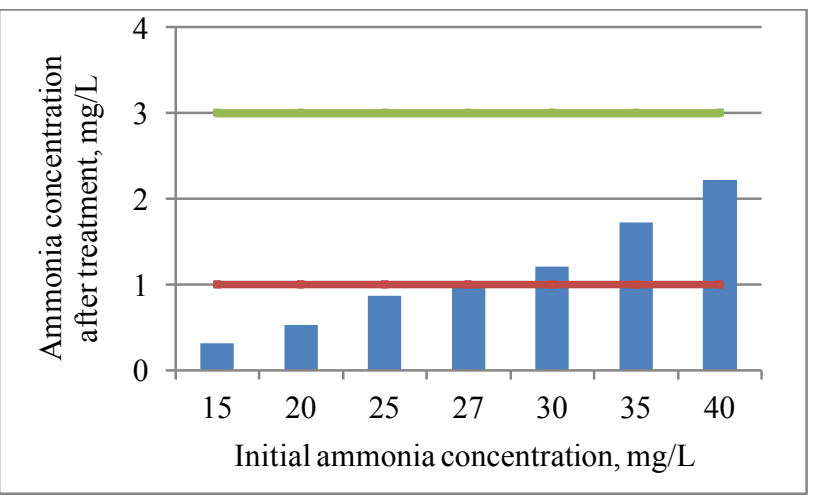

Figure 8. Ammonia concentration after treatment by $Z$ Na with different initial ammonium concentrations

According to the results of the study in figure 6, it was found that at each ammonium concentration a suitable amount of $\mathrm{Z}-\mathrm{Na}$ was required to reach the standard. With initial water solution with $\mathrm{C}_{\mathrm{N}-\mathrm{NH} 4+}<27 \mathrm{mg} / \mathrm{L}, \mathrm{C}_{\mathrm{Z}-\mathrm{Na}}=13 \mathrm{~g} / \mathrm{L}$, after 5 minutes can be treated with $\mathrm{C}_{\mathrm{N}-\mathrm{NH} 4+}=1 \mathrm{mg} / \mathrm{L}$ to QCVN 09:2015-MT/BTNMT. The processing efficiency was $96.30 \%$, the adsorption capacity was $5.88 \mathrm{mg} \mathrm{N}$ $\mathrm{NH}_{4}{ }^{+} / 1 \mathrm{~g} \mathrm{Z}-\mathrm{Na}$. With $\mathrm{C}_{\mathrm{Z}-\mathrm{Na}}=13 \mathrm{~g} / \mathrm{L}$, all concentrations of $\mathrm{C}_{\mathrm{N}-\mathrm{NH} 4+}<50 \mathrm{mg} / \mathrm{L}$ are possible to decrease down to $\mathrm{C}_{\mathrm{N}-\mathrm{NH} 4+}$ $<3 \mathrm{mg} / \mathrm{L}$, passed QCVN 02: 2009 / BYT.

\subsection{Z-Na desorption ability}

After treatment of ammonium containing solution $\mathrm{C}_{\mathrm{N}}$ $\mathrm{NH} 4+^{+}=80 \mathrm{mg} / \mathrm{L}$ by Z-Na concentration of $26 \mathrm{~g} / \mathrm{L}$, a solution containing $\mathrm{C}_{\mathrm{N}-\mathrm{NH} 4+}=2.96 \mathrm{mg} / \mathrm{L}$ was obtained. After treatment of Z-Na steaming with $2 \mathrm{~g} / \mathrm{L} \mathrm{NaOH}$, the solution obtained was $\mathrm{C}_{\mathrm{N}-\mathrm{NH} 4+}=70.96 \mathrm{mg} / \mathrm{L}$. Discharge efficiency is $92 \%$ of the amount of ammonia adsorbed. It was higher than $89 \%$ by ultrafine coal fly ash (Elizabeth $M$. van der Merwe et al., 2017) and $88 \%$ by illite flotation (Hao Jiang et al., 2018)

\subsection{Ammonia treatment in real sample}

After actual treatment with ammonium concentrations of $53 \mathrm{mg} / 1$ with Z-Na concentrations of 17.5 and $25 \mathrm{mg} / \mathrm{l}$, we have aqueous solution of ammonium with the concentration of $2 \mathrm{mg} / \mathrm{l}$, passed QCVN 02: 2009/BYT.

\section{Conclusion}

According to research results, at $\mathrm{pH}=6$, the efficiency of ammonium treatment in water is the best, the efficiency is over $95 \%$. The processing efficiency increased rapidly during the first 5 minutes, and remained almost unchanged, accounting for over $96 \%$ during the process. The higher the $\mathrm{Z}-\mathrm{Na}$ concentration, the higher the processing efficiency. With the initial solution concentration of $\mathrm{N}^{-\mathrm{NH}_{4}}{ }^{+}<27$ $\mathrm{mg} / \mathrm{L}, \mathrm{CZ}-\mathrm{Na}=13 \mathrm{~g} / \mathrm{L}$, after 5 minutes can be treated with solutions of $\mathrm{N}_{-} \mathrm{NH}_{4}{ }^{+}<1 \mathrm{mg} / \mathrm{L}$ (passed QCVN 09MT:2015/BTNMT). The processing efficiency was $96.30 \%$, the adsorption capacity was $5.88 \mathrm{mg} / \mathrm{g}$. Z-Na's desorption efficiency was $92 \%$.

\section{Recommendations}

Applying Z-Na material into real-life to treat ammonia in groundwater at family scale is needed to cary out. Producing liquid fertilizer from the solution that has a high concentration of $\mathrm{NH}_{4}^{+}$after $\mathrm{N}$-desorption of $\mathrm{Z}-\mathrm{Na}$ is recommended.

\section{References}

[1] *** (2016) Groundwater environment : Many parameters crossed the threshold, Resource and Environment report, 13/10/2016.

[2] Vu Thi Mai, Pham Van Tuyen (2016) Research on ammonium treatment in water environment of charcoal from cobs modified with $\mathrm{H}_{3} \mathrm{PO}_{4}$ and $\mathrm{NaOH}$, Journal of Science VNU, 06/09/2016.

[3] Nguyen Thi Ngoc, Research on ability to process ammonium in water with nanoparticles $\mathrm{MnO}_{2}-\mathrm{FeOOH}$ carried on Laterit.

[4] Nguyen Van Khoa, Research on fast determination method of ammonium ion and application to evaluate the current status of ammonium pollution in some domestic water sources in Hanoi. Master thesis.

[5] QCVN 09-MT:2015/BTNMT, National quality standards for underground water quality.

[6] QCVN 02:2009/BYT, National technical regulation on quality of water of living.

[7] I. Sancho, E. Licon, C. Valderrama, N. De Arespacochaga, S. López-Palau, J.L. Cortina (2017) Recovery of ammonia from domestic wastewater effluents liquid fertilizers by intergration of natural zeolites and hollow fibre membrance contactors, Science of the Total Enviromental, 584-585: 244-251.

[8] Elizabet M. van der Merwe, Clarissa L. Gray, Barbara A. Castleman, Sameera Mohamed, Richard A. Kruger, Frédéric J. Doucet., 2017. Ammonium sulphate and/or ammonium bisulphate as extracting agents for the recovery of aluminium from ultrafine coal fly ash. Hydrometallurgy 171: 185-190.

[9] Hao Jiang, Ya Gao, Qinhong Yang, Sultan Ahmed Khoso, Guorong Liu, Longhua Xu, Yuehua Hu., 2018. Adsorption behaviors and mechanisms of dodecyltrimethyl ammonium chloride and cetyltrimethyl ammonium chloride on illite flotation. Powder Technology 331: 218-225. 